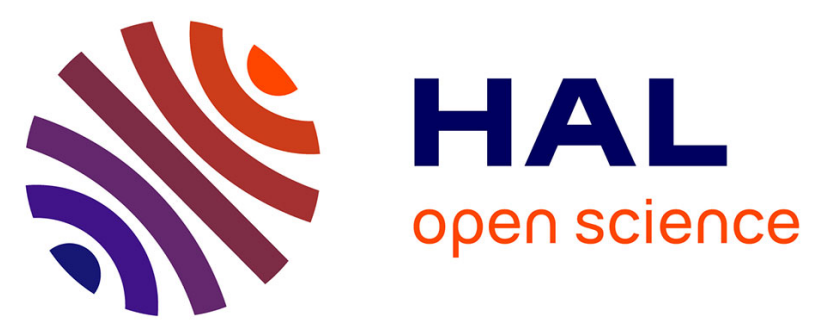

\title{
Identification of the silver state in the framework of Ag-containing zeolite by XRD, FTIR, photoluminescence, 109 Ag NMR, EPR, DR UV-vis, TEM and XPS investigations
}

Nataliia Popovych, Pavlo Kyriienko, Sergiy Soloviev, Rafal Baran, Yannick Millot, Stanislaw Dzwigaj

\section{To cite this version:}

Nataliia Popovych, Pavlo Kyriienko, Sergiy Soloviev, Rafal Baran, Yannick Millot, et al.. Identification of the silver state in the framework of Ag-containing zeolite by XRD, FTIR, photoluminescence, 109 Ag NMR, EPR, DR UV-vis, TEM and XPS investigations. Physical Chemistry Chemical Physics, 2016, 18, pp.29458-29465. 10.1039/c6cp05263k . hal-01387417

\section{HAL Id: hal-01387417 https://hal.sorbonne-universite.fr/hal-01387417}

Submitted on 9 Nov 2016

HAL is a multi-disciplinary open access archive for the deposit and dissemination of scientific research documents, whether they are published or not. The documents may come from teaching and research institutions in France or abroad, or from public or private research centers.
L'archive ouverte pluridisciplinaire HAL, est destinée au dépôt et à la diffusion de documents scientifiques de niveau recherche, publiés ou non, émanant des établissements d'enseignement et de recherche français ou étrangers, des laboratoires publics ou privés. 
Identification of the silver state in the framework of Ag-containing zeolite by XRD, FTIR, photoluminescence, ${ }^{109}$ Ag NMR, EPR, DR UV-vis, TEM and XPS Investigations

\author{
Nataliia Popovych ${ }^{\mathrm{a}}$, Pavlo Kyriienko ${ }^{\mathrm{a}}$, Sergiy Soloviev ${ }^{\mathrm{a}}$, Rafal Baran ${ }^{\mathrm{b}, \mathrm{c}}$, \\ Yannick Millot ${ }^{\mathrm{c}}$ and Stanislaw Dzwigaj, ${ }^{\mathrm{c}, *}$
}

${ }^{a}$ L.V.Pisarzhevsky Institute of Physical Chemistry of the NAS of Ukraine,

31 Prosp. Nauky, 03028 Kyiv, Ukraine

${ }^{\mathrm{b}}$ AGH University of Science and Technology al. A. Mickiewicza 30, 30-059 Krakow, Poland ${ }^{\mathrm{c}}$ Sorbonne Universités, UPMC Univ Paris 06, CNRS, UMR 7197, Laboratoire de Réactivité de Surface, 4 place Jussieu, F-75252, Paris, France

Figures: 13

Keywords: Silver, zeolite, postsynthesis, NMR, EPR, photoluminescence

*Corresponding author

Stanislaw Dzwigaj, e-mail : stanislaw.dzwigaj@upmc.fr, fax : +33 144272113 


\begin{abstract}
Silver has been identified in the framework of $\mathrm{Ag}_{\mathrm{x}} \mathrm{SiBEA}$ zeolites (where $\mathrm{x}=3-6 \mathrm{Ag}$ wt $\%$ ) by combined use of XRD, ${ }^{109} \mathrm{Ag}$ MAS NMR, FTIR, diffuse reflectance UV-visible, EPR and XPS. The incorporation of Ag ions into the framework of SiBEA zeolite has been evidenced by XRD. The consumption of $\mathrm{OH}$ groups as a result of their reaction with silver precursor has been monitored by FTIR and photoluminescence. The changes of the silver state as a function of Ag content, thermal and hydrogen treatment at $573 \mathrm{~K}$ have been identified by ${ }^{109} \mathrm{Ag}$ MAS NMR, EPR, DR UV-visible, TEM and XPS. The acidity of AgSiBEA has been investigated by FTIR spectroscopy of adsorbed CO and pyridine used as probe molecules.
\end{abstract}




\section{Introduction}

In recent years, increasing attention has been focused on the introduction of transition metals into zeolites and the use of the resulting materials as catalysts for various types of reactions. Zeolites containing transition metals are known to be efficient catalysts for selective catalytic reduction (SCR) of NO with different reducing agents [1-5], selective oxidation of methanol [6], oxidative dehydrogenation of propane [7,8], oxidation of $\mathrm{CO}$ [9], hydrodechlorination of chloroorganic compounds, hazardous pollutants of natural environment [10] or Fischer-Tropsch reaction of syngas to liquid hydrocarbons [11]. Catalysts based on BEA zeolites are widely investigated for industry processes and environmental protection due their high activity [5,12-14].

Interest in Ag-containing catalysts for the selective catalytic reduction of $\mathrm{NO}_{\mathrm{x}}$ was heightened after the finding that addition of hydrogen into the reaction mixture enhances the conversion of nitrogen oxide [15-18]. However, there is still lack of data in the literature concerning application of silver-containing zeolites in the SCR of $\mathrm{NO}_{\mathrm{x}}$. According to previous reports, dispersed silver species seem to be active catalytic centers of SCR of NO on Ag-MFI zeolites $[18,19]$. However, silver is not well dispersed in such materials, which contain silver in the form of various species, i.e., ions, nanoclusters, and metallic nanoparticles. Moreover, stabilization of silver in different oxidation states $\left(\mathrm{Ag}^{+}\right.$and $\left.\mathrm{Ag}^{2+}\right)$ may result in higher catalytic activity of $\mathrm{Ag}$-containing catalysts, as was shown earlier for $\operatorname{Sr}_{1-\mathrm{x}} \mathrm{Ag}_{\mathrm{x}} \mathrm{TiO}_{3 \pm \delta}$ perovskites [20]. $\mathrm{Ag}^{2+}$ ions, substituting part of $\mathrm{Sr}^{2+}$ in the lattice, could interact with some $\mathrm{O}_{\mathrm{x}}{ }^{-}$species, leading to $\mathrm{O}_{\mathrm{x}}{ }^{-} / \mathrm{Ag}^{2+}$ couples and so influencing oxygen mobility and catalytic activity.

To obtain well-dispersed silver species and to identify their state a two-step postsynthesis method was used, which developed earlier for preparation of metal-containing BEA zeolites [21,22]. This postsynthesis procedure allowed, for low metal content, 
incorporating of silver ions in the framework of zeolite mainly as isolated mononuclear silver species without formation of metal oligomers or metal oxides [23].

In the present work, we have identified silver state in the framework of Ag-containing BEA zeolites after different treatments using different physicochemical techniques such ${ }^{109} \mathrm{Ag}$ MAS NMR, EPR, UV-visible diffuse reflectance, and XPS.

\section{Experimental section}

\subsection{Materials}

TEABEA zeolite provided by RIPP (China) was treated in a $13 \mathrm{~mol} \cdot \mathrm{L}^{-1} \mathrm{HNO}_{3}$ aqueous solution $(4 \mathrm{~h}, 353 \mathrm{~K})$ to obtain a dealuminated and organic-free SiBEA support $(\mathrm{Si} / \mathrm{Al}=1000)$ with the vacant $\mathrm{T}$-atom sites. SiBEA was then washed with distilled water and dried at $353 \mathrm{~K}$. To incorporate Ag ions in the vacant T-atom sites two-step postsynthesis method were applied, described in our earlier report [23]. $2 \mathrm{~g}$ of SiBEA was firstly stirred under aerobic conditions for $2 \mathrm{~h}$ at $298 \mathrm{~K}$ in $200 \mathrm{~mL}$ of $\mathrm{AgNO}_{3}$ aqueous solution $(\mathrm{pH}=2.3$ ) with two concentration of 5.4 and $10.8 \times 10^{-3} \mathrm{~mol} \cdot \mathrm{L}^{-1}$. Then, the suspensions were stirred in evaporator under vacuum of a water pump for $2 \mathrm{~h}$ in air at $353 \mathrm{~K}$ until the water was evaporated. The resulting solids containing 3.0 and $6.0 \mathrm{Ag}$ wt. \% were labeled as $\mathrm{Ag}_{3.0} \mathrm{SiBEA}$ and $\mathrm{Ag}_{6.0} \mathrm{SiBEA}$, respectively.

The as prepared Ag-containing SiBEA materials were calcined at $773 \mathrm{~K}\left(100 \mathrm{~K} \mathrm{~h}^{-1}\right)$ over $3 \mathrm{~h}$ and denoted as $\mathrm{C}-\mathrm{Ag}_{3.0} \mathrm{SiBEA}$ and $\mathrm{C}-\mathrm{Ag}_{6.0} \mathrm{SiBEA}$. The materials were reduced in flowing $\mathrm{H}_{2}\left(100 \mathrm{~mL} \mathrm{~min}^{-1}\right)$ at $573 \mathrm{~K}$ for $1 \mathrm{~h}$ and denoted as Red-C-Ag ${ }_{3.0} \mathrm{SiBEA}$ and Red-C$\mathrm{Ag}_{6.0} \mathrm{SiBEA}$.

\subsection{Techniques}


X-ray fluorescence chemical analysis was performed at room temperature on SPECTRO X-LabPro apparatus.

XRD experiments were done on a PANalytical Empyrean diffractometer equipped with the $\mathrm{Cu} \mathrm{K} \alpha$ radiation $(\lambda=154.05 \mathrm{pm})$ in the $2 \theta$ range of $5^{\circ}-90^{\circ}$.

The stationary photoluminescence spectra were recorded on a Perkin-Elmer LS55 luminescence spectrometer at room temperature under ambient condition. The samples were excited with light of $250 \mathrm{~nm}$. The excitation spectra were taken at $400 \mathrm{~nm}$.

DR UV-vis spectra were recorded under ambient conditions on a Specord M40 (Carl Zeiss) with a standard diffuse reflectance unit.

X-ray photoelectron spectroscopy (XPS) measurements were performed with a hemispherical analyzer (PHOIBOS 100, SPECS Gmbh) using $\operatorname{MgK}_{\alpha}(1253.6 \mathrm{eV})$ radiation. The power of the X-ray source was $300 \mathrm{~W}$. The area of the sample analyzed was $\sim 3 \mathrm{~mm}^{2}$. The powder samples were pressed on an indium foil and mounted on a special holder. Binding energy (BE) for $\mathrm{Si}$ and $\mathrm{Ag}$ was measured by reference to the $\mathrm{O} 1 \mathrm{~s}$ peak at $532.5 \mathrm{eV}$, corresponding to the binding energy of oxygen bonded to silicon. Before analysis, samples were outgassed at room temperature to a pressure of $10^{-7} \mathrm{~Pa}$. All spectra were fitted with a Voigt function (a 70/30 composition of Gaussian and Lorentzian functions) in order to determine the number of components under each XPS peak.

${ }^{109} \mathrm{Ag}$ NMR spectra were recorded with a Bruker Avance 700 spectrometer at 32.74 $\mathrm{MHz}$ and with a low-frequency 4-mm CP/MAS probe. The spinning speed was $14 \mathrm{kHz}$. To eliminate acoustic ringing artifacts, the spectra were acquired with spin-echo pulse sequence $(\pi / 2-\tau-\pi-\tau)$, a $\pi / 2$ pulse duration of $10 \mu$ s and $10 \mathrm{~s}$ for recycle delay. Between 30000 to 50000 transients were acquired for each spectrum. Chemical shifts of silver were measured by reference to $\mathrm{AgSO}_{3} \mathrm{CH}_{3}(\delta=87.2 \mathrm{ppm})[24]$. 
EPR spectra were recorded on a JEOL FA-300 series EPR spectrometer at $9.3 \mathrm{GHz}$ (X band) using a $100 \mathrm{kHz}$ field modulation and a 5-10 G standard modulation width. The spectra were recorded at 298 and $77 \mathrm{~K}$ for fresh, calcined and reduced samples. The fresh $\mathrm{Ag}_{3.0} \mathrm{SiBEA}$ and $\mathrm{Ag}_{6.0} \mathrm{SiBEA}$ samples were calcined at $773 \mathrm{~K}$ for $2 \mathrm{~h}$ under a dynamic vacuum of $10^{-3} \mathrm{~Pa}$ at which led to the activated $\mathrm{C}-\mathrm{Ag}_{3.0} \mathrm{SiBEA}$ and C-Ag $\mathrm{Ag}_{6.0} \mathrm{SiBEA}$ samples, respectively. Then $\mathrm{C}-\mathrm{Ag}_{3.0} \mathrm{SiBEA}$ and $\mathrm{C}-\mathrm{Ag}_{6.0} \mathrm{SiBEA}$ samples were reduced by treatment with pure $\mathrm{H}_{2}$ at $573 \mathrm{~K}$ for $1 \mathrm{~h}$ what led to the Red-C- $\mathrm{Ag}_{3.0} \mathrm{SiBEA}$ and Red-C-Ag $\mathrm{g}_{6.0} \mathrm{SiBEA}$ samples.

TEM micrographs were obtained on SELMI TEM-125K microscope operating at 100 $\mathrm{kV}$. For TEM measurements a sample was dispersed in acetone with ultrasound and deposited on $\mathrm{Cu}$ grid covered with carbon. Interplanar spacings $\left(\mathrm{d}_{\mathrm{hkl}}\right)$ calculated from the diffraction ring pattern were compared with ASTM data.

Analysis of the acidic properties of samples was performed by adsorption of $\mathrm{CO}$ or pyridine followed by infrared spectroscopy. Before analysis, the samples were pressed at $\sim 1$ ton $\cdot \mathrm{cm}^{-2}$ into thin wafers of ca. $10 \mathrm{mg} \cdot \mathrm{cm}^{-2}$ and placed inside the IR cell.

Before $\mathrm{CO}$ adsorption experiment, the wafers were activated by calcination at $723 \mathrm{~K}$ for $2 \mathrm{~h}$ in flowing $2.5 \% \mathrm{O}_{2} / \mathrm{Ar}$ and then outgassed at $573 \mathrm{~K}\left(10^{-3} \mathrm{~Pa}\right)$ for $1 \mathrm{~h}$. Following thermal treatment, the samples were cooled down to $100 \mathrm{~K}$. CO was introduced in increasing amounts up to an equilibrium pressure of $133 \mathrm{~Pa}$. Infrared spectra were recorded using a Bruker Vertex 70 spectrometer (resolution $2 \mathrm{~cm}^{-1}, 128$ scans). The spectra were obtained after subtraction of the spectrum recorded after calcination and prior to $\mathrm{CO}$ adsorption.

Before pyridine adsorption/desorption experiments, the wafers were activated by calcination in static conditions at $773 \mathrm{~K}$ for $1 \mathrm{~h}$ in $\mathrm{O}_{2}\left(2 \cdot 10^{4} \mathrm{~Pa}\right)$ and then outgassing under secondary vacuum at $673 \mathrm{~K}\left(10^{-3} \mathrm{~Pa}\right)$ for $1 \mathrm{~h}$. These wafers were contacted at $423 \mathrm{~K}$ with gaseous pyridine. The spectra were recorded after pyridine desorption at $423 \mathrm{~K}$ using a Spectrum One FTIR spectrometer (resolution $2 \mathrm{~cm}^{-1}, 24$ scans). The reported spectra were 
obtained after subtraction of the spectrum recorded after calcination and prior to pyridine adsorption and recalculated to a "normalized" wafer of $1 \mathrm{mg}$.

\section{Results and discussion}

\subsection{Incorporation of Silver into SiBEA framework proved by XRD, FTIR and photoluminescence}

An analysis of zeolite BEA structure modifications may be done by XRD involving monitoring of the main reflection peak at $2 \theta=22.3^{\circ}-22.6^{\circ}$, corresponding to $\mathrm{d}_{302}$ spacing, within a given series of zeolite samples. The $\mathrm{d}_{302}$ spacing for all studied samples was calculated from the corresponding $2 \theta$ value. The $d_{302}$ spacing decreased from $3.979 \AA$ for TEABEA to $3.921 \AA$ for SiBEA indicating a matrix contraction, consistent with the removal of $\mathrm{Al}$ atoms from zeolite BEA structure. The introduction of $\mathrm{Ag}$ into SiBEA resulted in the increase of the $\mathrm{d}_{302}$ spacing from $3.921 \AA$ ( $\left.\mathrm{SiBEA}\right)$ with $2 \theta$ of $22.60^{\circ}$ to $3.950 \AA\left(\mathrm{Ag}_{3.0} \mathrm{SiBEA}\right)$ with $2 \theta$ of $22.49^{\circ}$ and to $3.945 \AA\left(\mathrm{Ag}_{6.0} \mathrm{SiBEA}\right)$ with $2 \theta$ of $22.51^{\circ}$ (Figure 1). Those changes in the position of the main diffraction peak suggest expansion of the BEA structure and the incorporation of silver ions into the vacant $\mathrm{T}$-atom sites forming isolated, mononuclear $\mathrm{Ag}(\mathrm{I})$ species in line with our earlier reports on VSiBEA [22] and MoSiBEA [25] zeolites. Furthermore, all diffractograms are typical of zeolite BEA phase with no proofs of the structure amorphization and appearance of other crystalline phases, suggesting that the removal of aluminum by nitric acid treatment did not damage zeolite structure.

The FTIR spectra of SiBEA and $\mathrm{Ag}_{6.0} \mathrm{SiBEA}$ are shown in the Figure 2. The incorporation of silver into SiBEA leads to the almost total disappearance of the IR bands at 3739,3715 and $3533 \mathrm{~cm}^{-1}$ of isolated internal, terminal internal and hydrogen bonded $\mathrm{SiOH}$ groups (Figure 2), suggesting that these silanol groups reacted with the Ag precursor. After 
incorporation of $\mathrm{Ag}$ ions in the vacant T-atom sites only the bands at $3752 \mathrm{~cm}^{-1}$ of isolated external silanol groups and the band at $3715 \mathrm{~cm}^{-1}$ of terminal internal silanol groups with very low intensity and the shoulder at $3740 \mathrm{~cm}^{-1}$ of isolated internal silanol groups are only present in $\mathrm{Ag}_{6.0} \mathrm{SiBEA}$ (see inset in Fig. 2).

The incorporation of $\mathrm{Ag}^{+}$ions into the vacant T-atom sites of the framework of BEA zeolite is confirmed by the photoluminescence spectroscopy. Figure 3 and 4 shows both photoluminescence and the excitation spectra of SiBEA and $\operatorname{Ag}_{3.0} \mathrm{SiBEA}$. The excitation spectrum of SiBEA exhibits broad band at about $249 \mathrm{~nm}$ with a shoulder at $262 \mathrm{~nm}$ (Fig. 4). They correspond to intense emission broad bands with maximum at about 400 and $645 \mathrm{~nm}$ (Fig. 3). The spectral distribution of the SiBEA photoluminescence obtained at $249 \mathrm{~nm}$ excitation light shown in Figure 3 is very similar to that recently reported for siliceous MCM41 and amorphous silica [26]. The emission bands at 400 and $645 \mathrm{~nm}$ are likely due to surface defects associated with $\mathrm{SiO}-$ and/or $\mathrm{SiOH}$ groups, in agreement with earlier reported data [27]. After incorporation of $\mathrm{Ag}$ ions in the SiBEA zeolite the intensity of the emission bands at 400 and $645 \mathrm{~nm}$ is strongly decreased (see the emission bands in Fig. 3 for $\mathrm{Ag}_{3.0} \mathrm{SiBEA}$ ) which confirm the reaction of $\mathrm{Ag}^{+}$ions with silanol groups of vacant T-atom sites. Simultaneously, the intensity of the bands at 249 and $262 \mathrm{~nm}$ on excitation spectrum monitored at $400 \mathrm{~nm}$ of emission light are also strongly decreased (Fig. 4).

\subsection{Nature of the silver in AgSiBEA zeolites evidenced by ${ }^{109} \mathrm{Ag}$ MAS NMR, EPR DR UV-Vis and XPS}

The ${ }^{109}$ Ag MAS NMR, EPR, DR UV-vis and XPS have been used to determine the nature of the silver in $\mathrm{AgSiBEA}$ zeolites.

${ }^{109} \mathrm{Ag}$ MAS NMR of $\mathrm{Ag}_{3.0} \mathrm{SiBEA}, \mathrm{Ag}_{6.0} \mathrm{SiBEA}$ and Red-C-Ag $\mathrm{Ag}_{6.0} \mathrm{SiBEA}$ are given in Fig. 5. For $\mathrm{Ag}_{3.0} \mathrm{SiBEA}$ only one silver signal is detected at $21.5 \mathrm{ppm}$ indicating the formation 
of only one main silver species in this sample, probably as isolated framework mononuclear $\operatorname{Ag}(\mathrm{I})$. The similar signal with chemical shift close to $20 \mathrm{ppm}$ has been earlier observed by Pavlovskaya at al. [27] for different Ag-containing zeolites.

For the sample with much higher $\mathrm{Ag}$ content $\left(\mathrm{Ag}_{6.0} \mathrm{SiBEA}\right)$ the one signal with chemical shift at -33.2 ppm appears. A decrease of the chemical shift with the Ag content could be explained by the formation of bigger $\mathrm{Ag}_{\mathrm{n}}{ }^{\delta_{+}}$clusters with paramagnetic character. It is well know that silver clusters could have different magnetic properties, in particular paramagnetic ones [28-36] that could modify chemical shift of the NMR signal, in line with the earlier reports on paramagnetic shift [37-40]. The paramagnetic character of $\mathrm{Ag}_{\mathrm{n}}{ }^{\delta_{+}}{ }^{\text {clusters }}$ present in as prepared $\mathrm{Ag}_{6.0}$ SiBEA has been confirmed by EPR investigation (Fig. 7). The EPR spectrum of as prepared $\mathrm{Ag}_{3.0} \mathrm{SiBEA}$ do not show any signal (Fig. 6), in contrast the EPR spectrum of as prepared $\mathrm{Ag}_{6.0} \mathrm{SiBEA}$ reveals the presence of paramagnetic signal with low intensity with $\mathrm{g}=2.00068$ (Fig. 7).

The modification of the Ag species with increase of the Ag content has been confirmed by DR UV-vis investigation of as prepared $\mathrm{Ag}_{3.0} \mathrm{SiBEA}$ and $\mathrm{Ag}_{6.0} \mathrm{SiBEA}$ (Fig. 8). Both samples exhibit the band at $245 \mathrm{~nm}$ attributed to the charge transfer transition between $4 d^{10}$ and $4 d^{9} 5 s^{1}$ levels of highly dispersed $\mathrm{Ag}(\mathrm{I})$ species (Fig. 8), in line with earlier reports [41-48]. The band at $245 \mathrm{~nm}$ for as prepared $\mathrm{Ag}_{6.0} \mathrm{SiBEA}$ is more pronounced than that for as prepared $\mathrm{Ag}_{3.0} \mathrm{SiBEA}$. Probably, this is related with the presence in the former ones of much bigger amount of isolated $\mathrm{Ag}_{\mathrm{n}}{ }^{\delta_{+}}$clusters. Two bands at 208 and 272-300 nm observed for both as prepared $\mathrm{Ag}_{3.0} \mathrm{SiBEA}$ and $\mathrm{Ag}_{6.0} \mathrm{SiBEA}$ are probably related to charge transfer transition in BEA framework observed also for silver-free SiBEA, as we have reported earlier [49]. 
Figure 9 shows the $\mathrm{Ag} 3 \mathrm{~d}_{3 / 2}$ and $3 \mathrm{~d}_{5 / 2}$ bands of calcined $\mathrm{C}-\mathrm{Ag}_{3.0} \mathrm{SiBEA}$ and $\mathrm{C}$ $\mathrm{Ag}_{6.0} \mathrm{SiBEA}$. One peak at binding energy $(\mathrm{BE})$ of $373.4-373.6 \mathrm{eV}\left(\mathrm{Ag} 3 \mathrm{~d}_{3 / 2}\right)$ and of $367.4-$ $367.6 \mathrm{eV}\left(\mathrm{Ag} 3 \mathrm{~d}_{5 / 2}\right)$ indicates that $\mathrm{Ag}(\mathrm{I})$ species is the main silver species in both calcined C$\mathrm{Ag}_{3.0} \mathrm{SiBEA}$ and $\mathrm{C}-\mathrm{Ag}_{6.0} \mathrm{SiBEA}$, in line with our earlier report [49].

After reduction of $\mathrm{C}-\mathrm{Ag}_{3.0} \mathrm{SiBEA}$ and $\mathrm{C}-\mathrm{Ag}_{6.0} \mathrm{SiBEA}$ the new phases are observed in XRD patterns of Red-C- $\mathrm{Ag}_{3.0} \mathrm{SiBEA}$ and $\mathrm{Red}-\mathrm{C}-\mathrm{Ag}_{6.0} \mathrm{SiBEA}$ with diffraction peaks at $2 \theta$ values of 38.10, 44.30, 64.30 and 77.28, which correspond to the (111), (200), (220) and (311) lattice planes of the face-centered cubic metallic silver (JCPDS: 03-065-2871) (Fig. 1). The very similar diffraction peaks have been reported earlier for Ag-SBA-15 obtained by direct synthesis [50].

After reduction of $\mathrm{C}-\mathrm{Ag}_{6.0} \mathrm{SiBEA}$ sample a knight shift of the NMR signal is observed for Red-C-Ag ${ }_{6.0} \operatorname{SiBEA}$ (Fig.5), arisen from the interaction with the conduction electrons [51]. The signal recorded at $5272 \mathrm{ppm}$ (Fig. 5) is associated with the presence of metallic nanoparticles, in line with earlier reports $[27,52,53]$. This is confirmed by DR UV-vis band at $375 \mathrm{~nm}$ for Red-C-Ag ${ }_{3.0}$ SiBEA and Red-C-Ag ${ }_{6.0}$ SiBEA (Fig. 8) and EPR signal of C$\mathrm{Ag}_{6.0} \mathrm{SiBEA}$ at $\mathrm{g}=2.00159$ and Red-C-Ag${ }_{6.0} \mathrm{SiBEA}$ at $\mathrm{g}=2.00155$ characteristic for silver nanoparticles (Fig. 7) [42,45,47]. The metallic nanoparticles are also formed in Red-C$\mathrm{Ag}_{3.0} \mathrm{SiBEA}$ as shown by the DR UV-vis band at $375 \mathrm{~nm}$ (Fig. 8) and in C-Ag $\mathrm{Ag}_{3.0} \mathrm{SiBEA}$ and Red-C- $\mathrm{Ag}_{3.0} \mathrm{SiBEA}$ as shown by EPR signal at $\mathrm{g}=2.00154$ and at $\mathrm{g}=2.00125$ characteristic for silver nanoparticles (Fig. 6) with much lower amount than that observed for C$\mathrm{Ag}_{6.0} \mathrm{SiBEA}$ and Red-C-Ag ${ }_{6.0} \mathrm{SiBEA}$ (Fig. 7).

Nanoparticles of silver with the average size of $10 \mathrm{~nm}$ were detected on TEM images

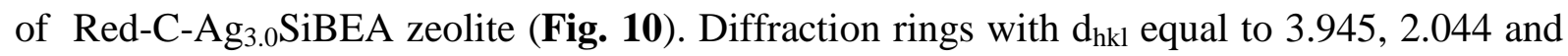
$1.183 \AA$ can be respectively assigned to $d_{302}$ spacing of BEA zeolite and (200), (222) planes of the face-centered cubic metallic silver. 


\subsection{FTIR characterization of acidic centres: adsorption of $\mathrm{CO}$ and pyridine}

To determine the acidity of $\mathrm{Ag}_{6.0} \mathrm{SiBEA}$ zeolites, the adsorption of $\mathrm{CO}$ and pyridine as probe molecules has been performed. The $\mathrm{CO}$ adsorption experiments give information on Bronsted acidity related to $\mathrm{OH}$ groups as well as on the nature and strength of Lewis acidic sites related to $\mathrm{Al}$ and $\mathrm{Ag}$ ions [54].

Difference spectra between FTIR spectra recorded after and before CO adsorption on $\mathrm{Ag}_{6.0} \mathrm{SiBEA}$ at $100 \mathrm{~K}$ are given in Figs 11 and 12. For $\mathrm{Ag}_{6.0} \mathrm{SiBEA}$ the adsorption of $\mathrm{CO}$ at $100 \mathrm{~K}$ leads to the appearance of only one main positive FTIR band at $3650 \mathrm{~cm}^{-1}$ and two negative bands at 3752 and $3715 \mathrm{~cm}^{-1}$ (Fig. 11). The 3752 and $3715 \mathrm{~cm}^{-1}$ bands correspond to isolated external and isolated internal $\mathrm{Si}-\mathrm{OH}$ groups. A very small shift from 3752 to 3650 $\mathrm{cm}^{-1}\left(102 \mathrm{~cm}^{-1}\right)$ for isolated external $\mathrm{Si}-\mathrm{OH}$ groups indicates that this silanol groups have a very weak acidic character.

FTIR spectra of $\mathrm{CO}$ adsorbed on $\mathrm{Ag}_{6.0} \mathrm{SiBEA}$ (Fig. 12) exhibit in the carbonyl region narrow and well-resolved bands in the 2050-2250 $\mathrm{cm}^{-1}$ range. For $\mathrm{Ag}_{6.0} \mathrm{SiBEA}$, in $\mathrm{CO}$ equilibrium, the main bands appear at 2135, 2138, 2142, 2159, 2170 and $2189 \mathrm{~cm}^{-1}$. However, after outgassing of the sample $\left(10^{-3} \mathrm{~Pa}\right.$ ), the main IR band appears at $2170 \mathrm{~cm}^{-1}$ (see inset in Fig. 12) that could be assigned to $\mathrm{CO}$ bonded to mononuclear $\mathrm{Ag}(\mathrm{I})$ species, in line with earlier report on Ag-zeolites [54,55] and $\mathrm{Ag} / \mathrm{SiO}_{2}[56]$. The $v(\mathrm{CO})$ stretching vibration of $\mathrm{Ag}^{+}-$ CO complexes, observed within the $2200-2150 \mathrm{~cm}^{-1}$ spectral range, depends on the type of the support, The carbonyls on $\mathrm{Ag}^{+} / \mathrm{SiO}_{2}$ are characterized by $v(\mathrm{CO})$ at $2169 \mathrm{~cm}^{-1}$ [56]. This value is close to that observed for $\mathrm{CO}$ adsorbed on $\mathrm{Ag}_{6.0} \mathrm{SiBEA}$ sample. 
The absence of the band at $3609 \mathrm{~cm}^{-1}$ in the IR spectrum of $\operatorname{Ag}_{6.0} \operatorname{SiBEA}$ (Fig. 2) characteristic of acidic bridging $\mathrm{Si}-\mathrm{O}(\mathrm{H})-\mathrm{Al}$ groups confirm that absorption band at $2170 \mathrm{~cm}^{-1}$ is only due to $\mathrm{CO}$ bonded to mononuclear $\mathrm{Ag}(\mathrm{I})$ species.

The acidity of SiBEA, $\mathrm{Ag}_{3.0} \mathrm{SiBEA}$ and $\mathrm{Ag}_{6.0} \mathrm{SiBEA}$ was also investigated by FTIR spectroscopy with adsorption of pyridine on the samples calcined at $773 \mathrm{~K}$ (Fig. 13). The bands at 1600 and $1448 \mathrm{~cm}^{-1}$ appear for SiBEA related to pyridine interacting with weak Lewis acidic sites and/or pyridine physisorbed $[57,58]$. The incorporation of silver in SiBEA leads to appearance of new bands at 1605 and $1450 \mathrm{~cm}^{-1}$, suggesting the formation of new silver Lewis acidic sites, as was shown earlier for $\mathrm{Ag}_{1.5}$ SiBEA zeolite [23]. The formation of silver LAS in zeolites may occur due to the interaction of silver with the gas phase oxygen. Adsorbed oxygen in this case is a conjugated base, i.e. Lewis conjugated acid-base pairs are formed on the oxidized silver species. Appearance of similar bands (1605 and $\left.1450 \mathrm{~cm}^{-1}\right)$ has been earlier observed for AgHZSM-5 zeolites prepared by ion-exchange $[59,60]$ and was assigned to pyridine adsorbed on silver species $\left(\mathrm{Ag}^{+}\right.$or $\left.\mathrm{Ag}_{\mathrm{n}}^{+}\right)$.

The intensity of the bands corresponding to silver Lewis acidic sites grows with increasing Ag content, which may indicate higher amount of isolated mononuclear $\operatorname{Ag}(\mathrm{I})$ species incorporated in the zeolite framework for $\mathrm{Ag}_{6.0} \mathrm{SiBEA}$.

\section{Conclusions}

The two-step postsynthesis method used in preparation of AgSiBEA zeolites allowed incorporation of silver ions in the framework of BEA zeolite as isolated mononuclear $\mathrm{Ag}(\mathrm{I})$ species.

Silver has been identified in the framework of $\mathrm{Ag}_{\mathrm{x}} \mathrm{SiBEA}$ zeolites (where $\mathrm{x}=3-6 \mathrm{Ag}$ wt \%) by combined use of XRD, ${ }^{109} \mathrm{Ag}$ MAS NMR, diffuse reflectance UV-visible, EPR and XPS. 
The incorporation of $\mathrm{Ag}$ ions into framework of SiBEA zeolite has been evidenced by XRD by monitoring of the main reflection peak at $2 \theta=22.3^{\circ}-22.6^{\circ}$, corresponding to $\mathrm{d}_{302}$ spacing.

The consumption of $\mathrm{OH}$ groups as a result of their reaction with silver precursor has been monitored by FTIR and photoluminescence.

${ }^{109}$ Ag MAS NMR, EPR, DR UV-visible, TEM and XPS allowed identifying the changes of the silver state as a function of Ag content, thermal and hydrogen treatment at $573 \mathrm{~K}$. To the best of our knowledge, this is the first time that changes of silver state in the zeolite structure have been determined using simultaneously ${ }^{109} \mathrm{Ag}$ MAS NMR, EPR and DR UV-visible spectroscopies.

The acidity of AgSiBEA has been investigated by FTIR spectroscopy of adsorbed CO and pyridine used as probe molecules. 


\section{References}

[1] P.S. Metkar, M.P. Harold, V. Balakotaiah, Appl. Catal. B 2012, 111-112, 67-80.

[2] P. S. Metkar, M. P. Harold, V. Balakotaiah, Chem. Eng. Sci. 2013, 87, 51-66.

[3] O. Krocher, M. Elsener, Ind. Eng. Chem. Res. 2008, 47, 8588-8593.

[4] B. Gil, J. Janas, E. Wloch, Z. Olejniczak, J. Datka, B. Sulikowski, Catal. Today 2008, 137, 174-178.

[5] J. Janas, S. Dzwigaj, Catal. Today 2011, 176, 272-276.

[6] M. Trejda, M. Ziolek, Y. Millot, K. Chalupka, M. Che, S. Dzwigaj J. Catal. 2011, 281, 169-176.

[7] A.K. Chalupka, C. Thomas, Y. Millot, F. Averseng, S. Dzwigaj, J. Catal. 2013, 305, 46-55.

[8] J. Janas, J. Gurgul, R.P. Socha, J. Kowalska, K. Nowinska, T. Shishido, M. Che, S.

Dzwigaj,_J. Phys. Chem. C 2009, 113, 13273-13281.

[9] I. Kocemba, J. Rynkowski, J. Gurgul, R.P. Socha, K. Latka, J. M. Krafft, S. Dzwigaj, Appl. Catal. B 2016, 519, 16-26

[10] A. Śrębowata, I. Zielińska, R. Baran, G. Słowik, S. Dzwigaj. Catal. Commun. 2015, 69, $154-160$.

[11] K. A. Chalupka, S. Casale, E. Zurawicz, J. Rynkowski, S. Dzwigaj, Micropor. Mesopor. Mater. 2015, 211, 9-18.

[12] S. Dzwigaj, J. Janas, T. Machej, M. Che, Catal. Today 2007, 119 133-136.

[13] J. Janas, T. Machej, J. Gurgul, L.P. Socha, M. Che, S. Dzwigaj, Appl. Catal. B 2007, 75 239-248.

[14] J. Janas, J. Gurgul, R.P. Socha, S. Dzwigaj, Appl. Catal. B 2009, 91, 217-224.

[15] S. Satokawa, Chem. Lett. 2000, 29, 294-295.

[16] J.P. Breen, R. Burch, C.J. Hill, Catal. Today 2009, 145, 34-37. 
[17] N.O. Popovych, P.I. Kyriienko, S.O. Soloviev, S.M. Orlyk, S. Dzwigaj, Micropor.

Mesopor. Mater. 2016, 226, 10-18.

[18] J. Shibata, K. Shimizu, Y. Takada, A. Shichi, H. Yoshida, S. Satokawa, A. Satsuma, T. Hattori, J. Catal. 2004, 227, 367-374.

[19] K. Shimizu, K. Sugino, K. Kato, S. Yokota, K. Okumura, A. Satsuma, J. Phys. Chem. C 2007, 111, 1683-1688.

[20] L. Fabbrini, A. Kryukov, S. Cappelli, G.L. Chiarello, I. Rossetti, C. Oliva, L. Forni, J. Catal. 2005, 232, 247-256.

[21] S. Dzwigaj, M.J. Peltre, P. Massiani, A. Davidson, M. Che, T. Sen, S. Sivasanker, Chem. Commun. 1998, 87-88.

[22] S. Dzwigaj, Curr. Opin. Solid State Mater. Sci. 2003, 7, 461.

[23] S. Dzwigaj, Y. Millot, J-M. Krafft, N. Popovych, P. Kyriienko, J. Phys. Chem. C 2013, $117,12552$.

[24] G. H. Penner and W. Li, Inorg. Chem. 2004, 43, 5588-5597.

[25] R. Baran, F. Averseng, Y. Millot, T. Onfroy, S. Casale and S. Dzwigaj, J. Phys. Chem. C, 2014, 118, 4143-4150.

[26] M.E. Gimon-Kinsel, K. Groothuis, K.J. Balkus, Micropor. Mesopor. Mater. 1998, 20, 67-76.

[27] G. E. Pavlovskaya, C. F. Horton-Garcia, C. Dybowski, D. R. Corbin and T. Meersmann, J. Phys. Chem. B, 2004, 108, 1584-1589.

[28] A. Baldansuren and E. Roduner, Chem. Phys. Lett. 2009, 473, 135-137.

[29] J. Michalik, Appl. Magn. Reson., 1996, 10, 507-537.

[30] J. Michalik, L. Kevan, J. Am. Chem. Soc. 1986, 108, 4247-4253.

[31] J. Michalik, J. Sadlo, T. Kodaira, S. Shimomura, H. Yamada, J. Radioanal. Nucl. Chem. 1998, 232, 135-137. 
[32] J. Michalik, A. Van der Pol, E. J. Reijerse, T. Wasowicz, E. De Boer, Appl. Magn. Reson. 1992, 3, 19-35.

[33] J. Michalik, T. Wasowicz, J. Sadlo, E. J. Reijerse, L. Kevan, Radiat. Phys. Chem. 1996, 47, 75-81.

[34] J. R. Morton, K. F. Preston, J. Magn. Reson., 1986, 68, 121-128.

[35] M. Pereiro, D. Baldomir, J. E. Arias, Phys. Rev. A 2007, 75, 063204-1/063204-5

[36] T. Sun, K. Seff, Chem. Rev. 1994, 94, 857-870.

[37] V. I. Bakhmutov, Chem Rev, 2011, 111, 530-562.

[38] C. P. Grey, C. M. Dobson, A. K. Cheetham, R. J. B. Jakeman, J. Am. Chem. Soc. 1989, 111, 505-511.

[39] C. P. Grey, M. E. Smith, A. K. Cheetham, C. M. Dobson, R. Dupree, J. Am. Chem. Soc. 1990, 112, 4670-4675.

[40] G. Pintacuda, G. Kervern, Top. Curr. Chem. 2013, 335, 157-200.

[41] N. E. Bogdanchikova, V. P. Petranovskii, R. Machorro M, Y. Sugi, V. M. Soto G, S. Fuentes M, Appl. Surf. Sci. 1999, 150, 58-64.

[42] O. Y. Golubeva, N. Y. Ul'yanova, Glass Phys. Chem. 2015, 41, 537-544.

[43] M. Matsuoka, W.-S. Ju, H. Yamashita and M. Anpo, J. Photochem. Photobiol. A 2003, $160,43-46$.

[44] K. Sato, T. Yoshinari, Y. Kintaichi, M. Haneda, H. Hamada, Appl. Catal., B 2003, 44, $67-78$.

[45] A. Satsuma, J. Shibata, K.-I. Shimizu, T. Hattori, Catal. Surv. Asia 2005, 9, 75-85.

[46] P. Sazama, L. Capek, H. Drobna, Z. Sobalik, J. Dedecek, K. Arve, B. Wichterlova, J. Catal. 2005, 232, 302-317.

[47] J. Shibata, Y. Takada, A. Shichi, S. Satokawa, A. Satsuma, T. Hattori, J. Catal. 2004, 222, 368-376. 
[48] B. Wichterlova, P. Sazama, J. P. Breen, R. Burch, C. J. Hill, L. Capek, Z. Sobalik, J. Catal. 2005, 235, 195-200.

[49] S. Dzwigaj, N. Popovych, P. Kyriienko, J-M. Krafft, S. Soloviev, Micropor. Mesopor. Mater. 2013, 189, 16-24.

[50] M. Boutros, J.M. Trichard, P. Da Costa, Appl. Catal. B 2009, 91, 640-648.

[51] J. J. van der Klink, H. B. Brom, Prog. Nucl. Magn. Reson. Spectrosc. 2000, 36, 89-201.

[52] J. K. Plischke, A. J. Benesi, M. A. Vannice, J. Phys. Chem. 1992, 96, 3799-3806.

[53] K. Son, Z. Jang, J. Korean Phys. Soc. 2013, 62, 292-296.

[54] K. Hadjiivanov, G.N. Vayssilov, Adv. Catal. 2002, 47, 307-511.

[55] Y.Y. Huang, J. Catal. 1974, 32, 482-491.

[56] K. Hadjiivanov, H. Knözinger, J. Phys. Chem. B 1998, 102, 10936-10940.

[57] G. Centi, G. Gollinetti, G. Busca, J. Phys. Chem. 1990, 94, 6813-6819.

[58] G. Busca, G. Centi, F. Trifiro, V. Lorenzelli, J. Phys. Chem. 1986, 90, 1337-1344.

[59] X. He, X. Huang, Z. Wang, Y. Yan, Micropor. Mesopor. Mater. 2011, 142, 398-403.

[60] R. Zhang, Z. Wang, Chin. J. Chem. Eng. 2015, 23, 1131-1137 


\section{Figure captions}

Figure 1. XRD recorded at ambient atmosphere of $\mathrm{SiBEA}, \mathrm{Ag}_{3.0} \mathrm{SiBEA}$, Red-C-Ag ${ }_{3.0} \mathrm{SiBEA}$, $\mathrm{Ag}_{6.0} \mathrm{SiBEA}$ and Red-C-Ag${ }_{6.0} \mathrm{SiBEA}$.

Figure 2. FTIR spectra recorded at $100 \mathrm{~K}$ of $\mathrm{SiBEA}$ and $\mathrm{C}-\mathrm{Ag}_{6.0} \mathrm{SiBEA}$ calcined at $773 \mathrm{~K}$ for $2 \mathrm{~h}$ in flowing $2.5 \% \mathrm{O}_{2} / \mathrm{Ar}\left(50 \mathrm{~mL} \mathrm{~min}^{-1}\right)$ and then outgassed at $573 \mathrm{~K}\left(10^{-3} \mathrm{~Pa}\right)$ for $1 \mathrm{~h}$.

Figure 3. Photoluminescence spectra of SiBEA and $\mathrm{Ag}_{3.0} \mathrm{SiBEA}$ with the excitation of 250 nm.

Figure 4. The excitation spectra of $\mathrm{SiBEA}$ and $\mathrm{Ag}_{3.0} \mathrm{SiBEA}$ monitored at $400 \mathrm{~nm}$ emission light.

Figure 5. ${ }^{109} \mathrm{Ag}$ MAS NMR spectra of $\mathrm{Ag}_{3.0} \mathrm{SiBEA}, \mathrm{Ag}_{6.0} \mathrm{SiBEA}$ and Red-C-Ag $\mathrm{A}_{6.0} \mathrm{SiBEA}$ recorded at room temperature and MAS frequency of $14 \mathrm{kHz}$

Figure 6. EPR spectra recorded at $77 \mathrm{~K}$ of $\mathrm{Ag}_{3.0} \mathrm{SiBEA}(\mathrm{a}), \mathrm{C}-\mathrm{Ag}_{3.0} \mathrm{SiBEA}$ (b) and Red-C$\mathrm{Ag}_{3.0} \mathrm{SiBEA}(\mathrm{c})$ samples.

Figure 7. EPR spectra recorded at $77 \mathrm{~K}$ of $\mathrm{Ag}_{6.0} \operatorname{SiBEA}(\mathrm{a}), \mathrm{C}-\mathrm{Ag}_{6.0} \mathrm{SiBEA}$ (b) and Red-C$\mathrm{Ag}_{6.0} \mathrm{SiBEA}(\mathrm{c})$ samples.

Figure 8. DR UV-vis spectra recorded at ambient atmosphere of as prepared and reduced $\mathrm{Ag}_{3.0} \mathrm{SiBEA}$ and $\mathrm{Ag}_{6.0} \mathrm{SiBEA}$.

Figure 9. XP spectra recorded at room temperature of $\mathrm{Ag} 3 \mathrm{~d}$ of calcined $\mathrm{Ag}_{3.0} \mathrm{SiBEA}$ and $\mathrm{Ag}_{6.0} \mathrm{SiBEA}$.

Figure 10. TEM image and diffraction patterns of Red-C- $\mathrm{Ag}_{3.0} \mathrm{SiBEA}$.

Figure 11. FTIR difference spectra $(\mathrm{OH}$ stretching range) recorded at room temperature of C$\mathrm{Ag}_{6.0} \mathrm{SiBEA}$ (calcined at $773 \mathrm{~K}$ for $2 \mathrm{~h}$ in flowing $2.5 \% \mathrm{O}_{2} / \mathrm{Ar}\left(50 \mathrm{~mL} \mathrm{~min}{ }^{-1}\right)$, outgassed at $573 \mathrm{~K}\left(10^{-3} \mathrm{~Pa}\right)$ for $1 \mathrm{~h}$ after adsorption of $\mathrm{CO}$ at $100 \mathrm{~K}$ : equilibrium $\mathrm{CO}$ pressure of $100 \mathrm{~Pa}$ (a) and development of the spectra during evacuation at $100 \mathrm{~K}(\mathrm{~b}-\mathrm{e})$ ). 
Figure 12. FTIR difference spectra (carbonyl stretching region) recorded at room temperature of C- $\mathrm{Ag}_{6.0} \mathrm{SiBEA}$ (calcined at $773 \mathrm{~K}$ for $2 \mathrm{~h}$ in flowing $2.5 \% \mathrm{O}_{2} / \mathrm{Ar}\left(50 \mathrm{~mL} \mathrm{~min}^{-1}\right)$, outgassed at $573 \mathrm{~K}\left(10^{-3} \mathrm{~Pa}\right)$ for $1 \mathrm{~h}$ after adsorption of $\mathrm{CO}$ at $100 \mathrm{~K}$ : equilibrium $\mathrm{CO}$ pressure of $100 \mathrm{~Pa}$ (a) and development of the spectra during evacuation at $100 \mathrm{~K}(\mathrm{~b}-\mathrm{e})$ ).

Figure 13. FTIR difference spectra recorded at room temperature of SiBEA, $\mathrm{Ag}_{3.0} \mathrm{SiBEA}$ and $\mathrm{Ag}_{6.0} \mathrm{SiBEA}$ after calcination at $773 \mathrm{~K}, 1 \mathrm{~h}$ in $\mathrm{O}_{2}\left(2 \cdot 10^{4} \mathrm{~Pa}\right)$, outgassing at $10^{-3} \mathrm{~Pa}$ for $1 \mathrm{~h}$ at $673 \mathrm{~K}$, adsorption of pyridine and desorption of pyridine at $423 \mathrm{~K}$. 


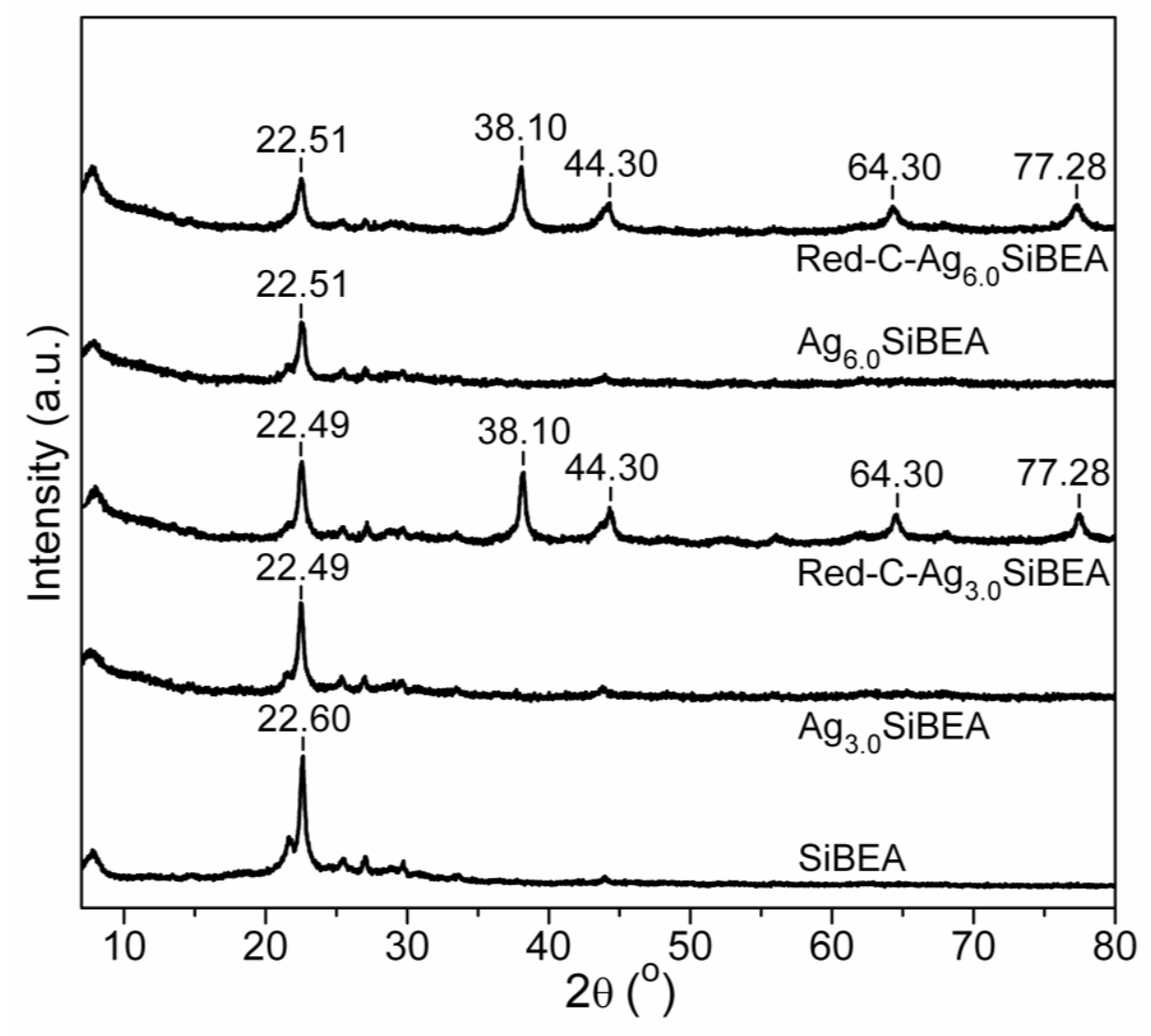

Figure 1 


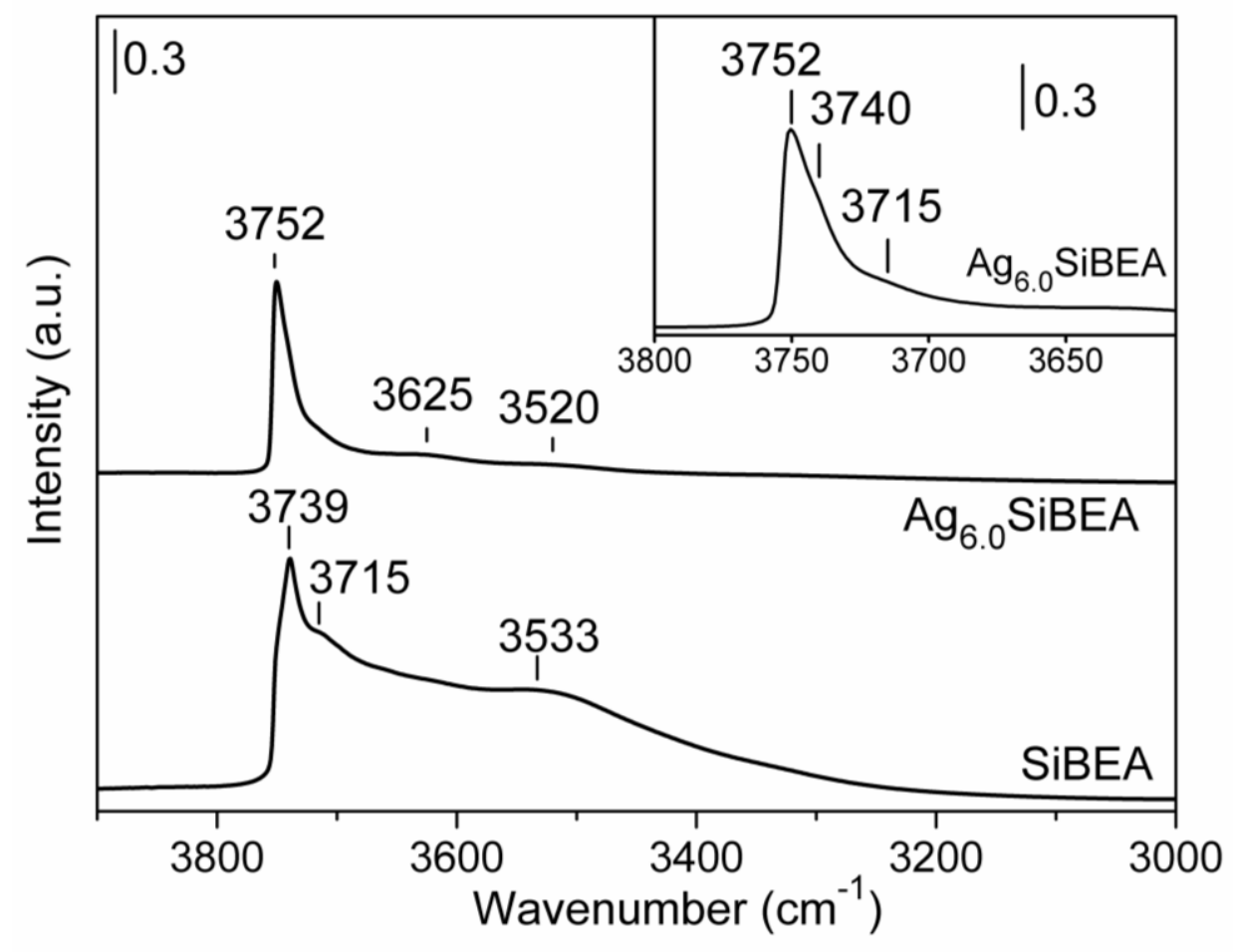

Figure 2 


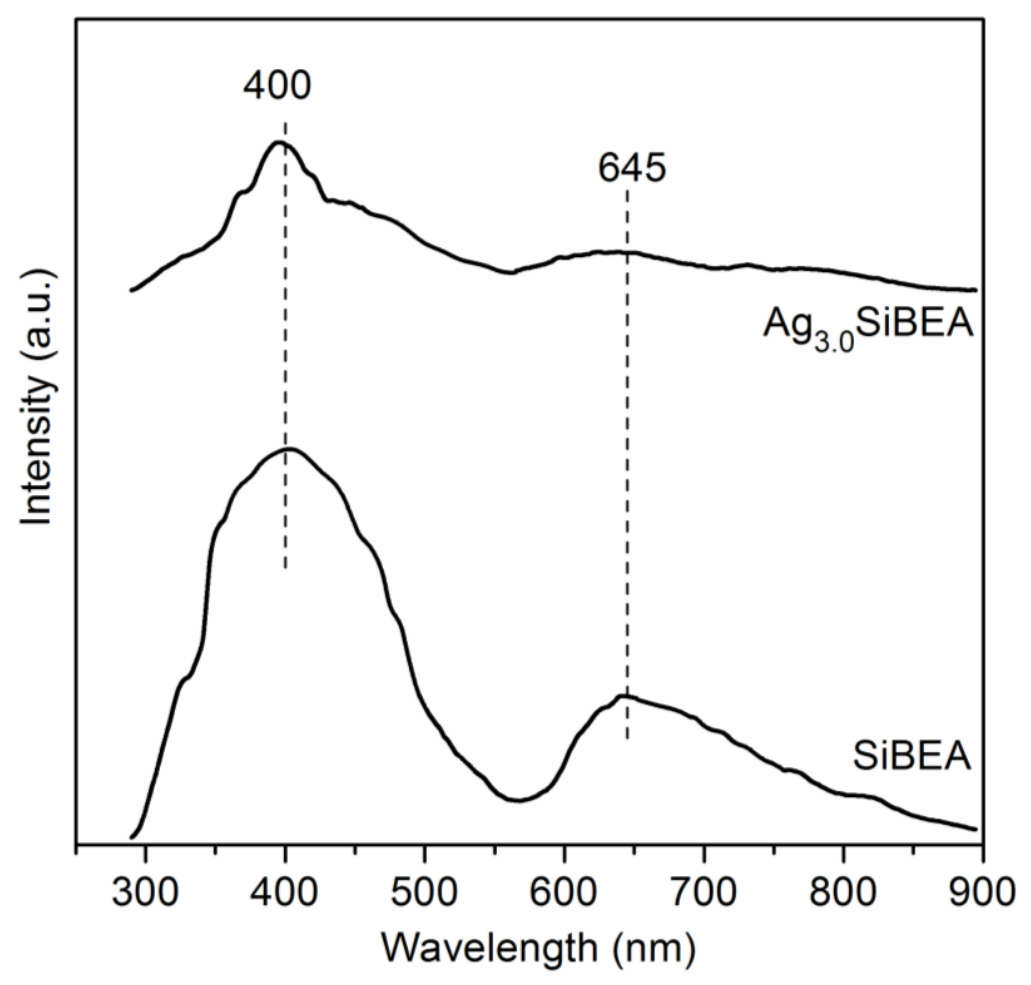

Figure 3 


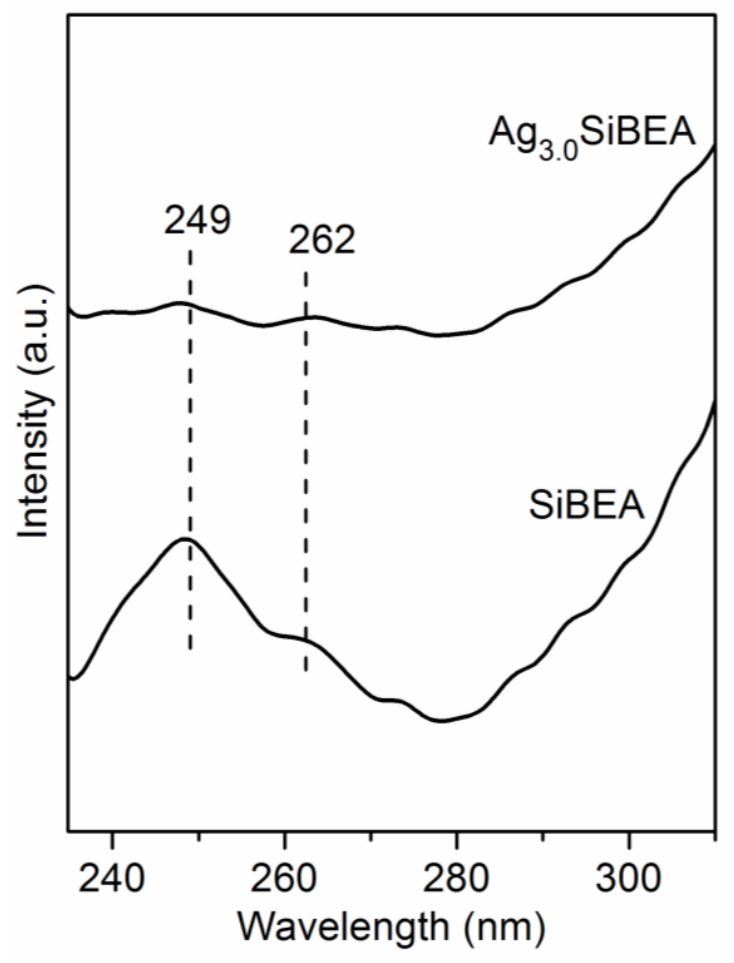

Figure 4 


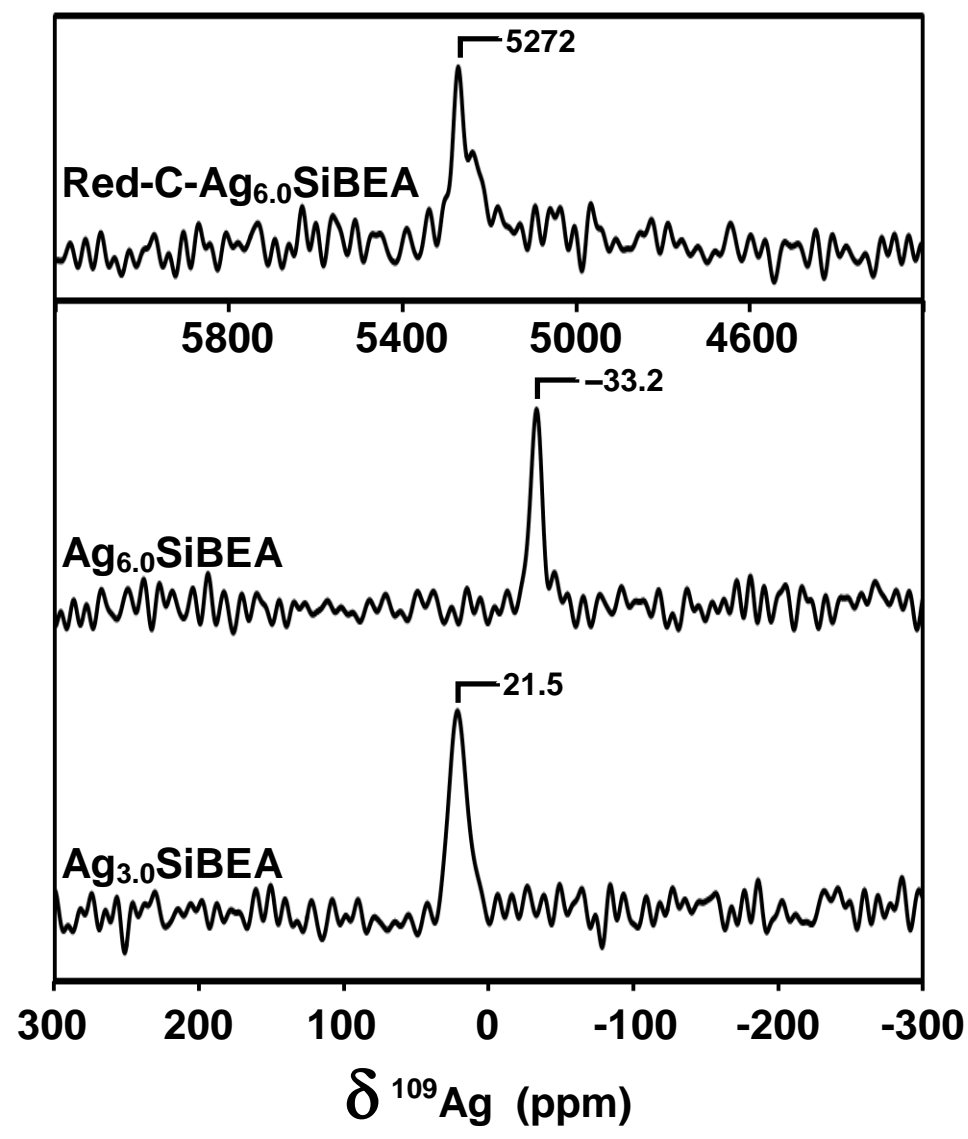

Figure 5 


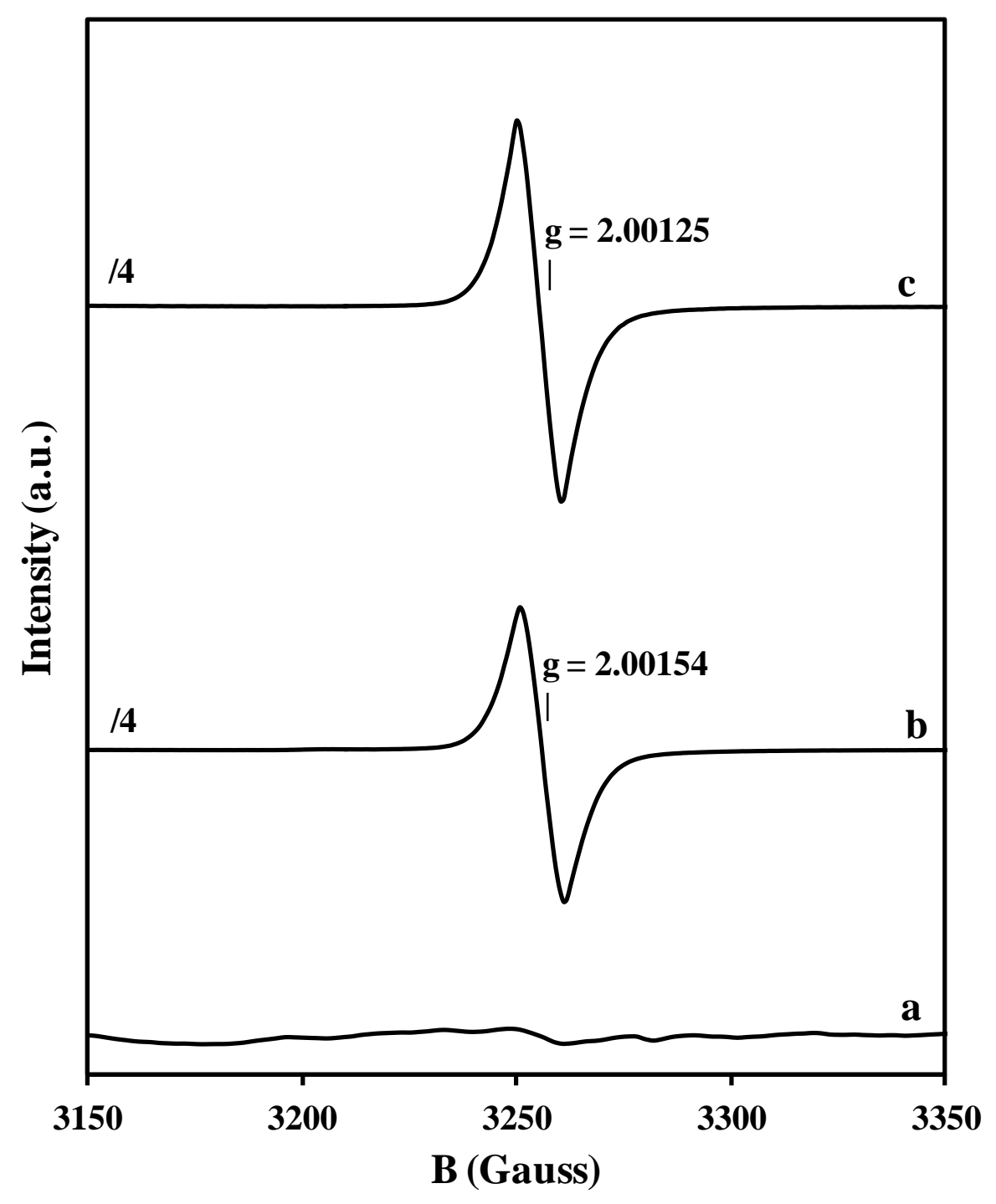

Figure 6 


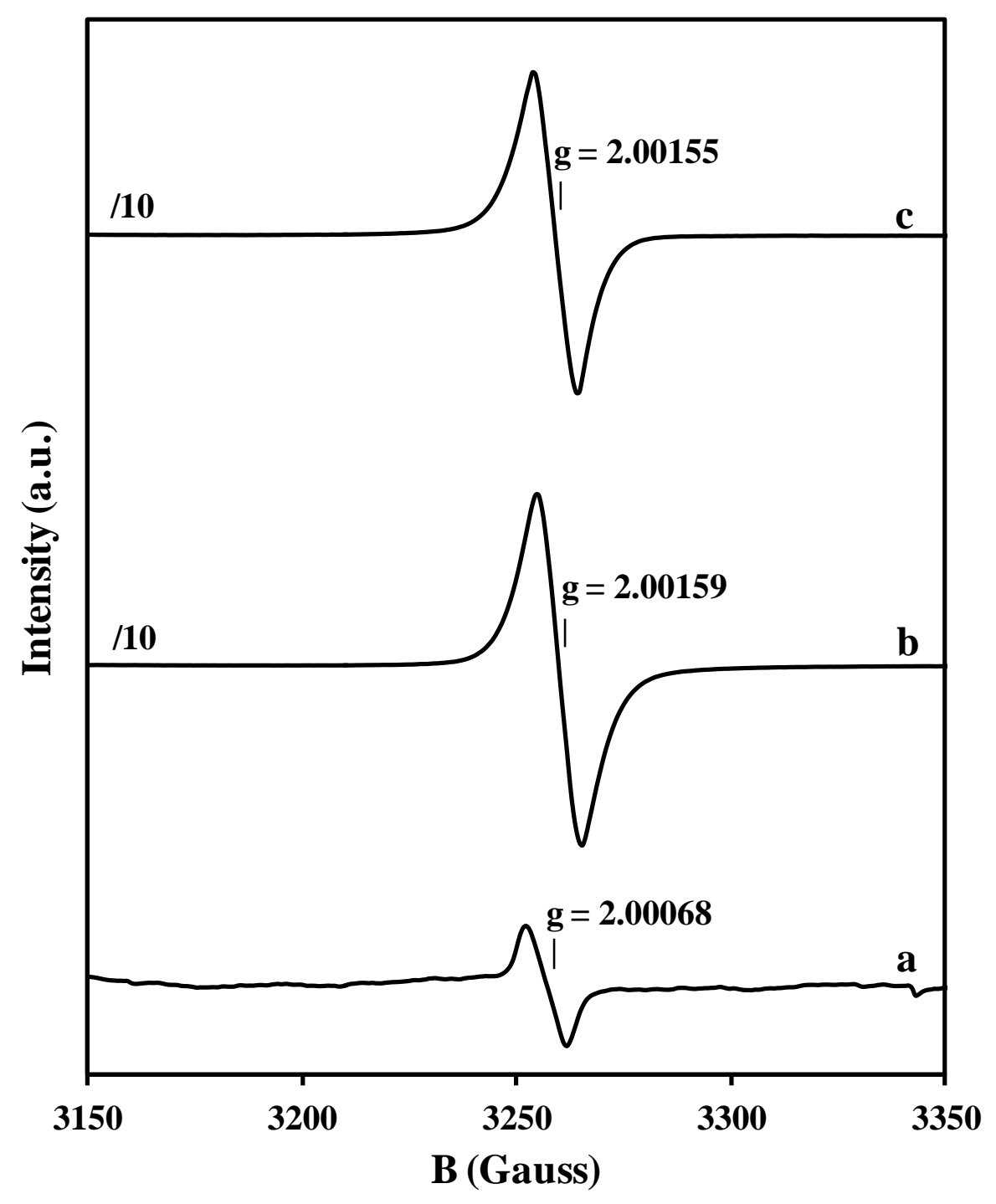

Figure 7 


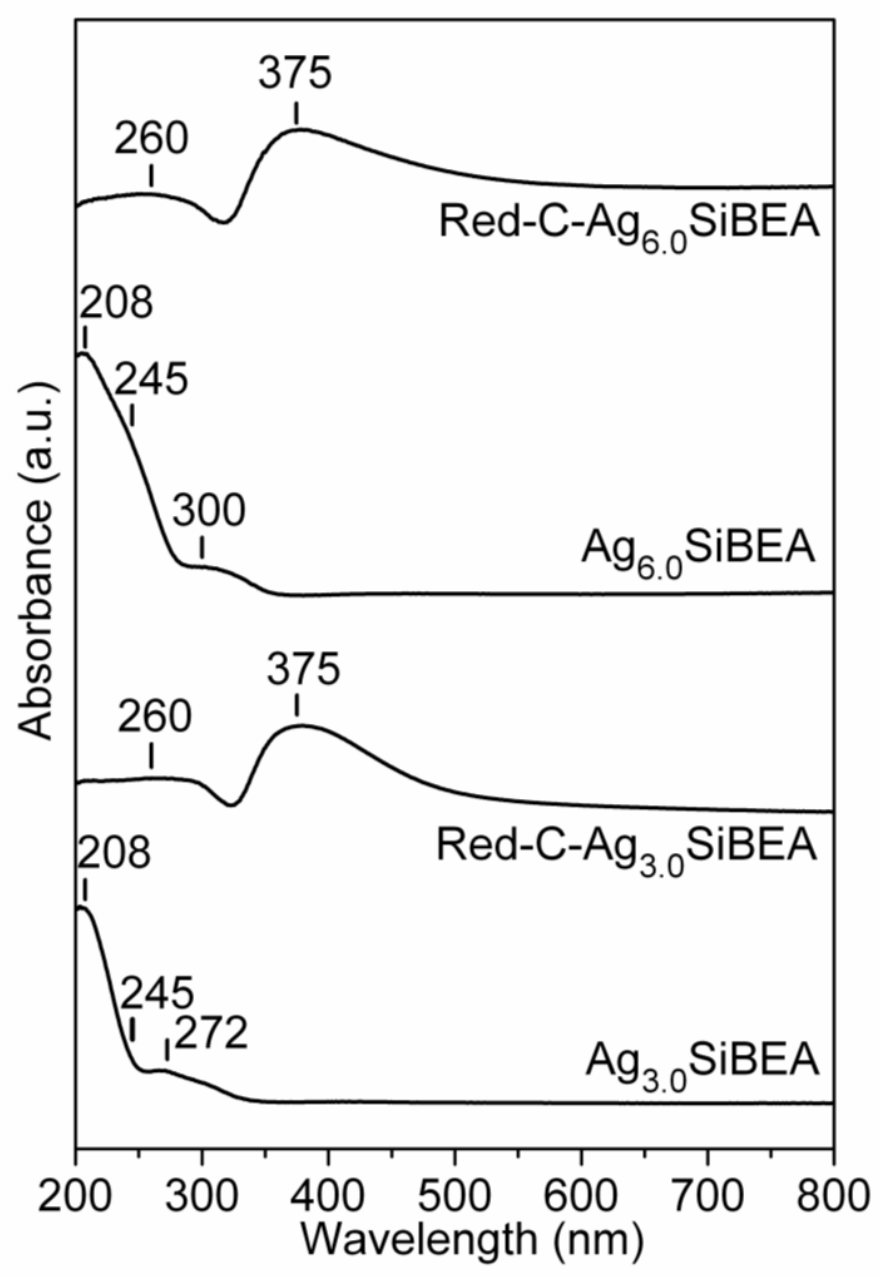

Figure 8 


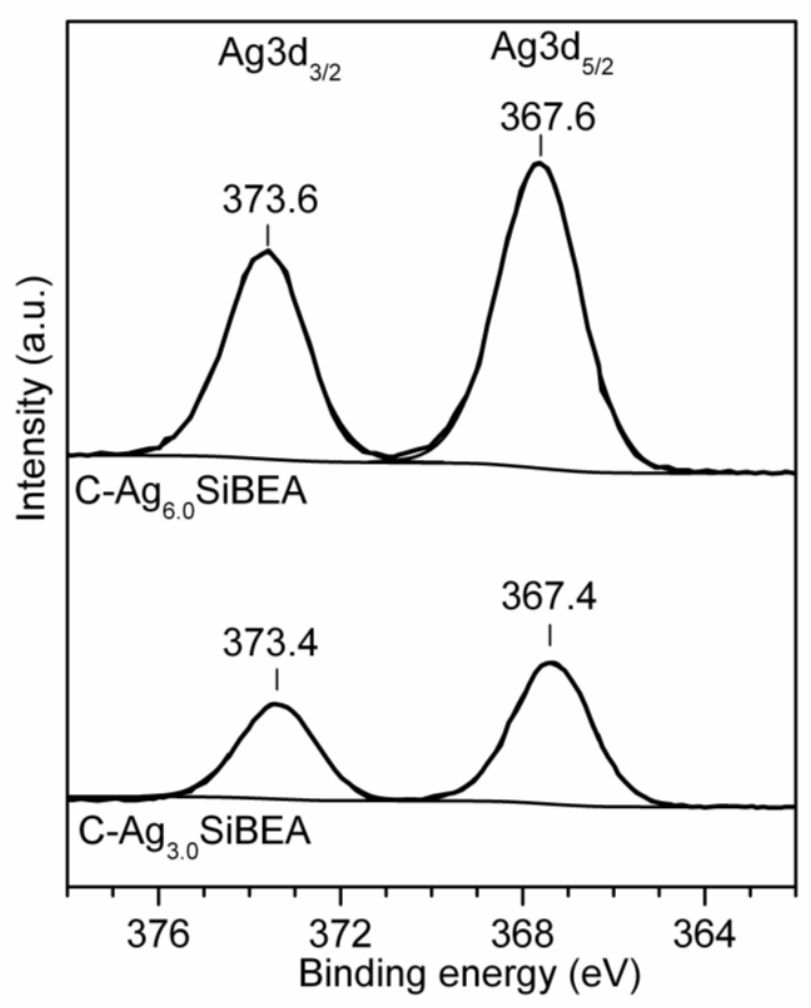

Figure 9 


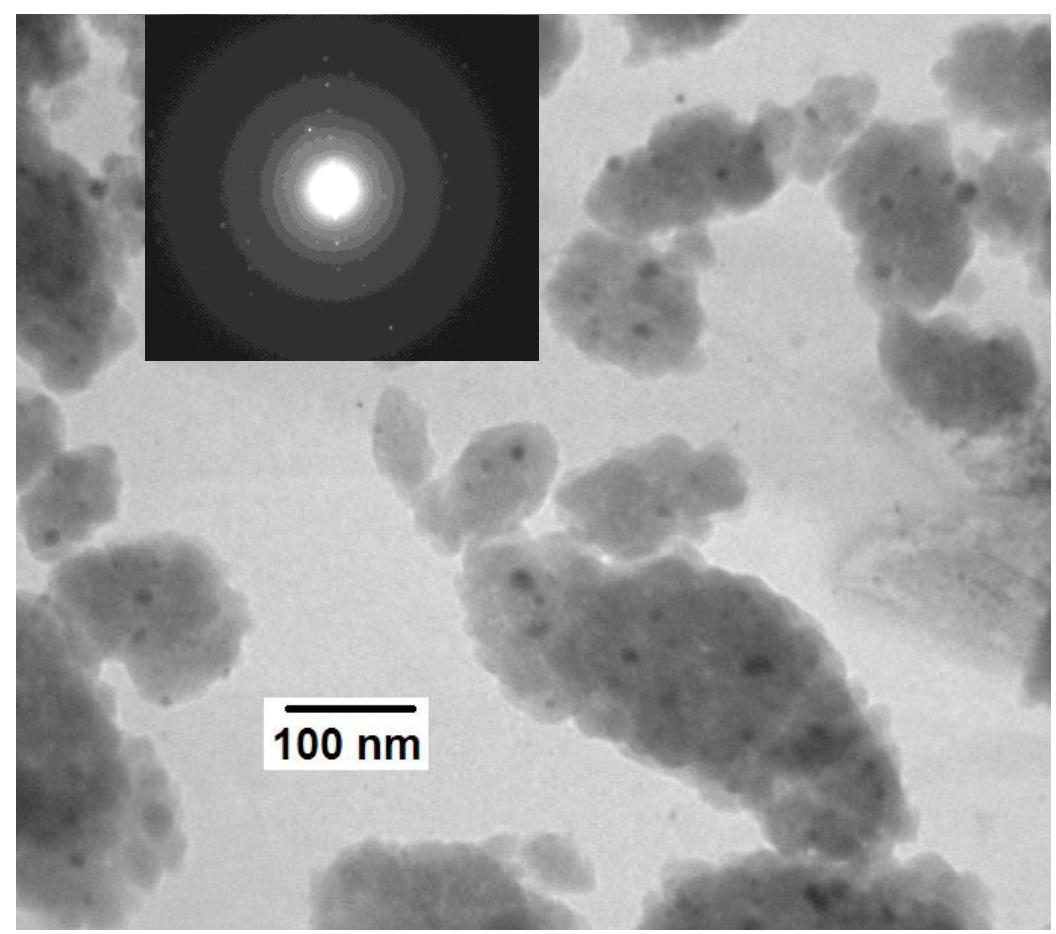

Figure 10 


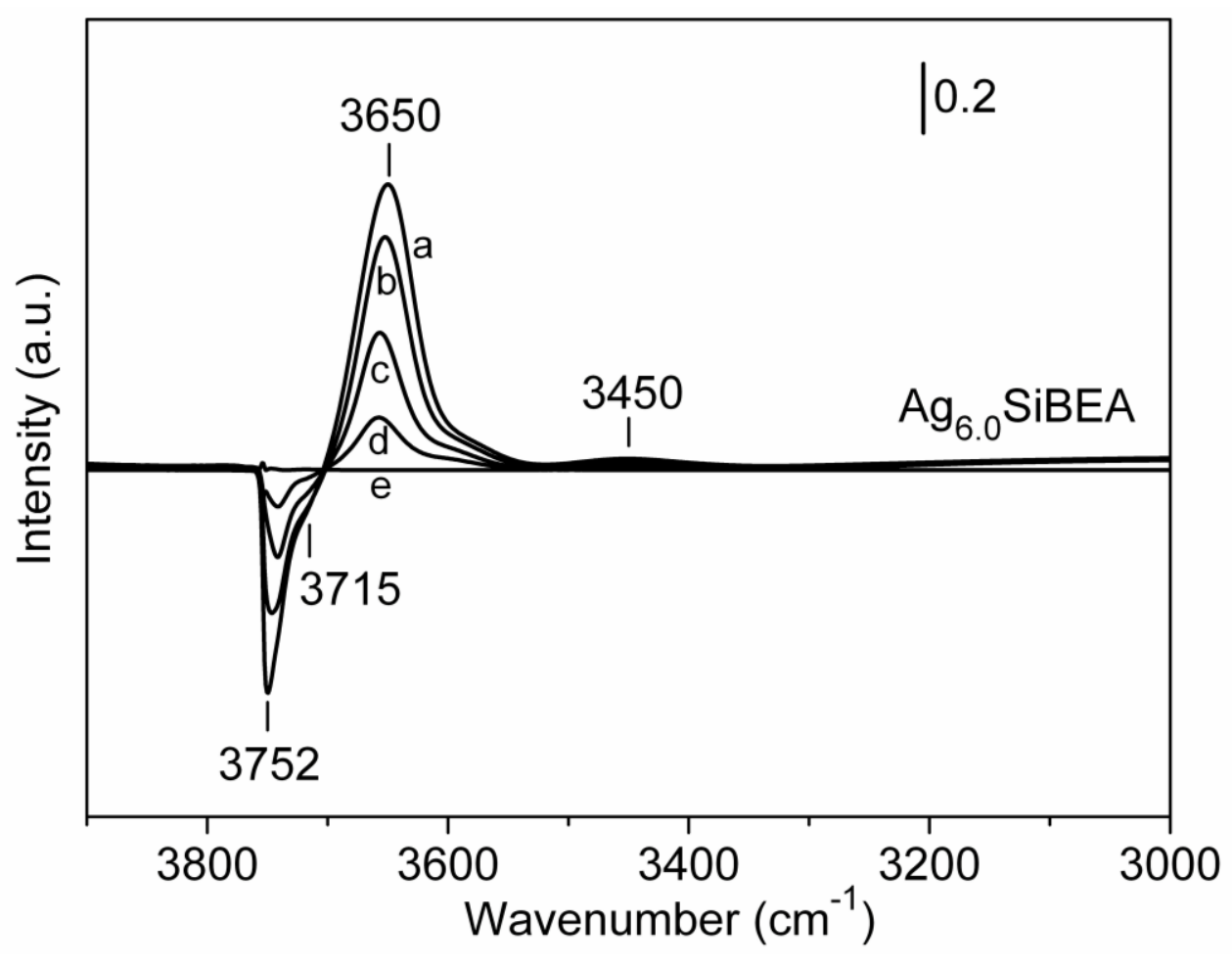

Figure 11 


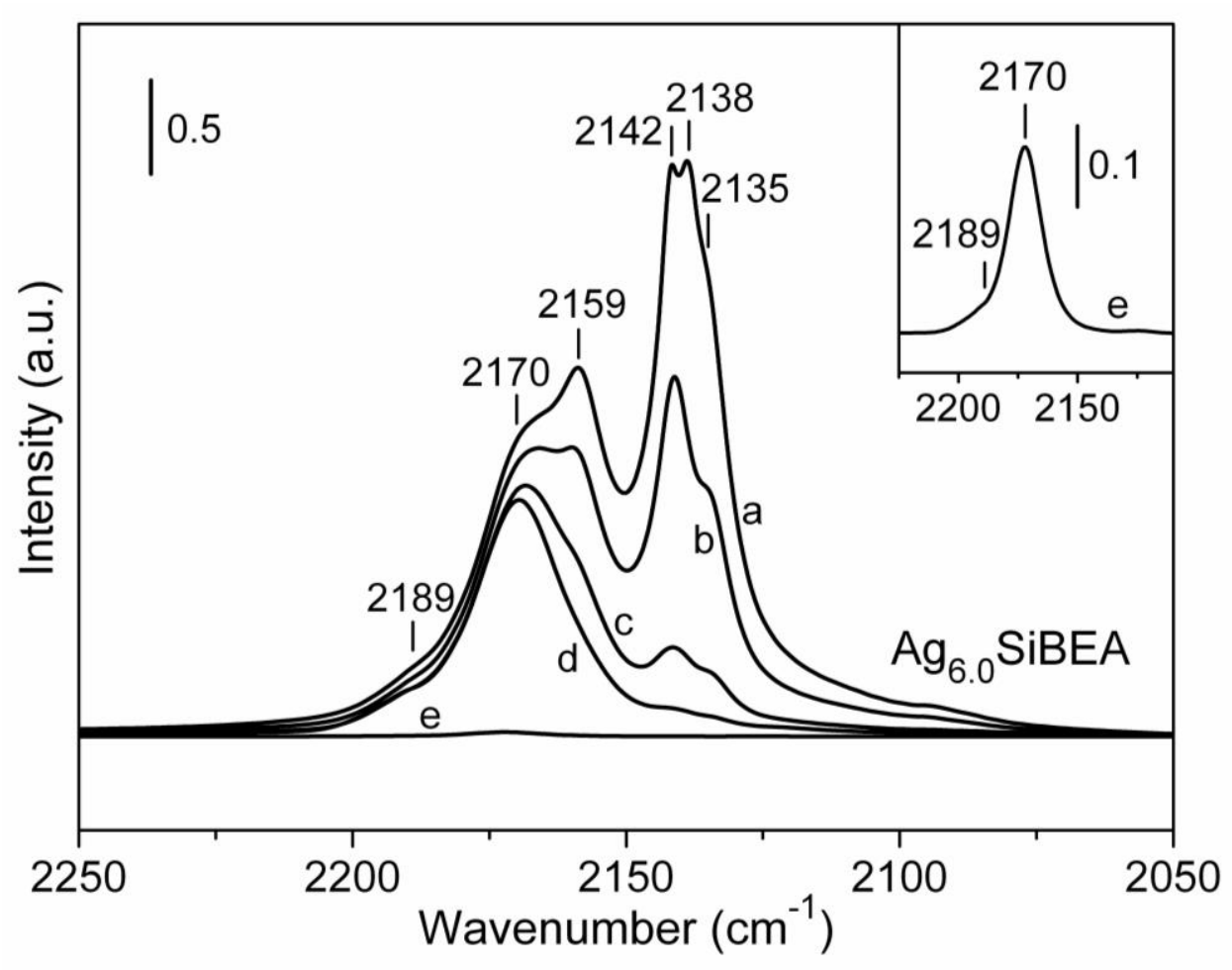

Figure 12 


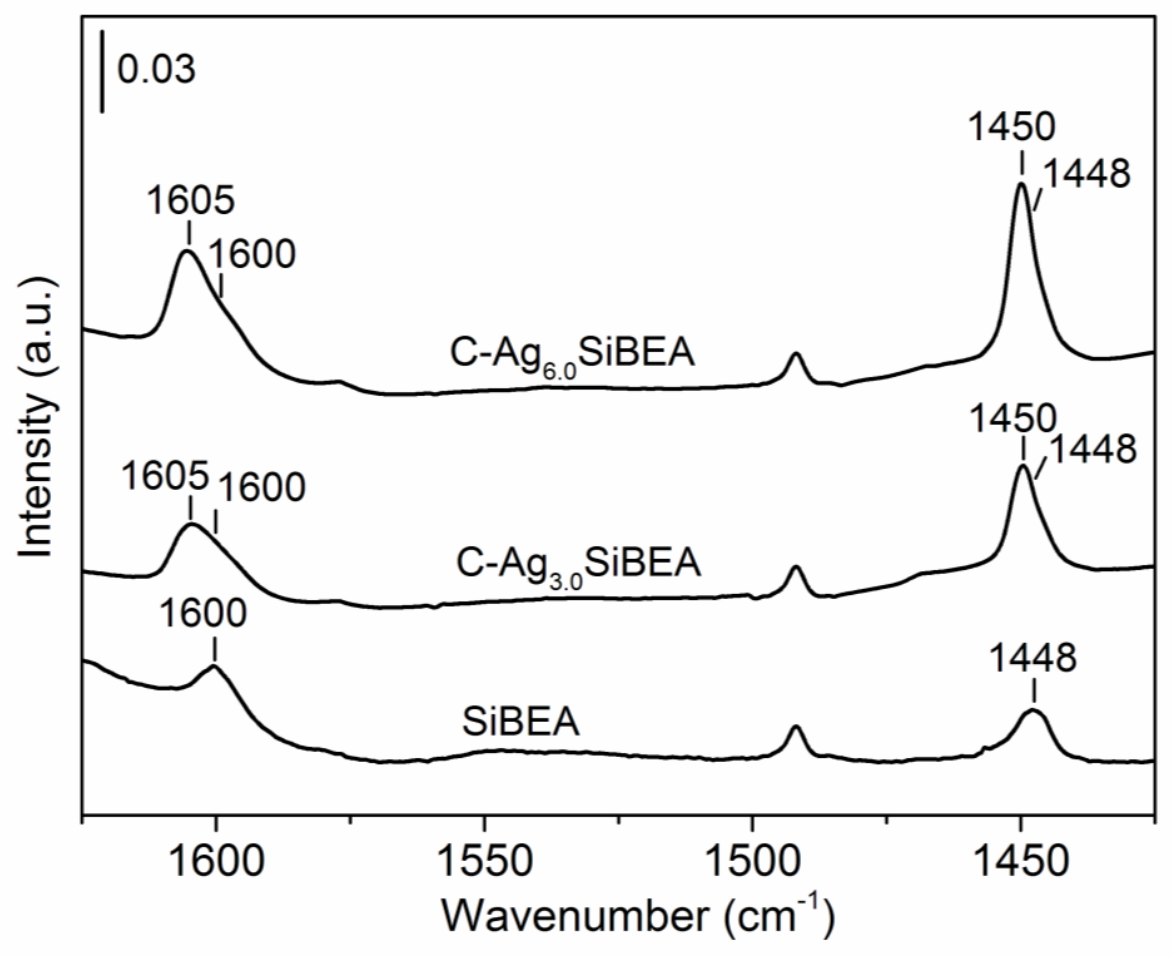

Figure 13 